\title{
Model of the New LMS Generation with User-Created Content
}

\author{
Dragan Perakovic, Vladimir Remenar and Ivan Jovovic \\ University of Zagreb, Faculty of Transport and Traffic Sciences
}

Croatia

\section{Introduction}

The Learning Management System (LMS), designed by the Faculty of Transport and Traffic Sciences, has been in use since 2004, when it was developed according to both the German Fachhochschule concept and specific requirements of studying in the Republic of Croatia at that time. The system consists of 5 individual modules (DMS, SAN, e-Student, SMSCentar i FPZmobile) which in mutual synergy represent the LMS of the Faculty. The Document Management System (DMS) is a system used for managing documents and processes used by the Faculty staff for authorized access to the modules for monitoring work in computer labs, e-Learning system administration (publication of instructional materials, checking and evaluating of seminar papers, etc.), and the module for managing documents and processes within the Faculty (equipment orders, malfunction reporting, updating of the online directory, etc.). The Authorization and Control System (SAN) is a combination of technologies and applications which enable monitoring of students working in the computer labs of the Faculty and personalization of working environment in the Windows operating system, regardless of which computer a student is working on. The e-Student System enables students to have authorized access to instructional materials, exercises and instructions. Furthermore, the system provides support to registration and preparation of seminar papers as well as other forms of testing (e-Blitz, e-Test, e-Quiz).

The SMSCentre and SAN system, supported by the smsCRM application (Customer Relationship Management via SMS), present possibilities for a wide range of information services, based on interactive communication through text messages, available to both students and the Faculty staff alike. Within the last three years the m-Learning module has been added to the e-Learning System of the Faculty in the form of an interactive application, called the FPZmobile, which provides real time information to students through mobile terminal devices. The basic idea was to develop an application which would offer accurate and up-to-date information about the Faculty and students' achivements (seminars, practical courses, preliminary exams, etc.) to all students while studying at the Faculty in the form adapted for viewing on interfaces of mobile terminal devices such as mobile phones, PDA devices and Smartphones. The modularity of this system enables quick implementation of new services developed in accordance with the ideas and suggestions provided by the teaching and non-teaching staff as well as students.

The e-Student module, as part of the Faculty's LMS, has been in use for five academic years. Although there have been improvements in the quality of the studies, the module has also 
indicated the existence of problems arising from the system processes, technologically obsolete equipment as well as the inability to support the Bologna process and the "Outcomes of Studying at the University of Zagreb" program ("Ishodi učenja na Sveučilištu u Zagrebu" - SveZaIU, 2009). The system is currently used by all 509 courses at the Faculty, serving 7,489 students and 362 staff. Over the past few years the system has been used almost 850,000 times by students and almost 50,000 by instructors. The number of published materials, altogether 5,645 data files, is still significantly smaller than the number of data files created and published by the most important users of the system: the students! Students have published 16,000 topics for seminar papers and more than 15,000 seminar papers. The LMS gives students freedom in working which they gradually accept. It has been noticed that the system is increasingly used in the period between 24:00 and 08:00, whereas working in the period between 08:00 and 16:00 is becoming less and less popular, as shown in Fig. 1.

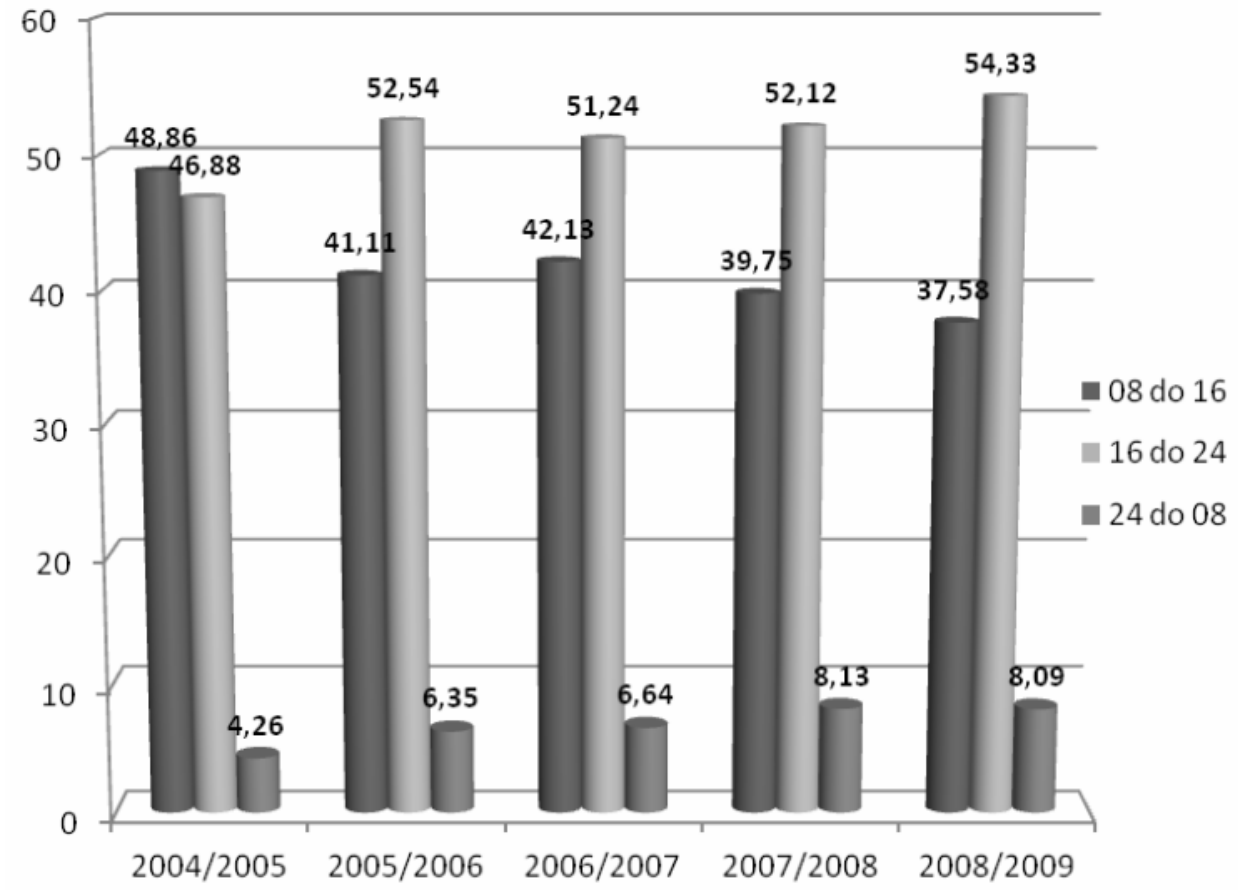

Fig. 1. Percentages of accessing the LMS according to the periods of the day

It is necessary to minimize or completely eliminate the negative aspects of the LMS usage as well as the shortcomings in the operation of the existing system in order to reach the desired level of the quality of studies. For this purpose, an entirely new system will be developed, based on the model described in this paper. The new system will be adapted to the needs of studying according to the Bologna process and in accordance with the "Outcomes of Studying at the University of Zagreb" program ("Ishodi učenja na Sveučilištu u Zagrebu" SveZaIU, 2009), the ISVU system (Infromation System of Higher Education Institutions) as well as the current trends in learning technology and communication both between students 
and between students and teachers. Furthermore, the model proposed in this paper will provide guidelines for developing the system according to the e-Learning 2.0 paradigm, which makes use all the Web.2.0 tools, such as Wiki, Blog, forums, social networking and others, in its operation.

\section{Initial development}

The e-Learning System of the Faculty of Transport and Traffic Sciences was designed, developed and implemented in 2004 to satisfy the needs of studying according to the German Fachhochschule concept as well as the specific requirements for studying in the Republic of Croatia. There are five modules currently in function (DMS, SAN, e-Student, SMSCentar and FPZmobile) which together represent the Learning Management System (LMS) of the Faculty of Transport and Traffic Sciences.

\subsection{Why we started}

As information and communication technologies and accompanying services developed, so did the idea of having their own distance learning system at the Faculty of Transport and Traffic Sciences. The idea was to develop a distance learning system which would become an indispensable tool in an electronic interactive communication in the teaching process and student welfare. That would make the Faculty of Transport and Traffic Sciences one of the first faculties in the Republic of Croatia to help students acquire and test their current knowledge more easily by using new technologies. Keeping that in mind, new hardware and software conditions were created in order to develop the Faculty's own LMS, which has been constantly improved and used since 2004.

\subsection{The system currently in function}

The DMS (Document Management System) is a system used for managing documents and processes used by the Faculty staff for authorized access to the modules: monitoring of work in the computer labs (checking of the access to exercises, etc.), system of e-Learning administration (publication of teaching materials, checking and evaluating of seminar papers, etc.), and the module for managing documents and processes within the Faculty (equipment orders, malfunction reporting, updating of the online directory, etc.).

The SAN (Croatian: Sustav autorizacije i nadzora, English: The authorization and control system) is a combination of technologies and applications which enable monitoring of students working in the computer labs of the Faculty and personalization of working environment in the Windows operating system, regardless of which computer a student is working on. The SAN system consists of 6 modules (SAN Server, SAN Application, SAN Client, SAN Administration, SAN Web and FPZBrowser), which are currently used to monitor three computer labs, and public computers located in the Faculty building.

The e-Student system, as shown in Fig. 2, enables authorized access to the teaching materials, tasks, exercises and instructions to students. Furthermore, the system provides support for the registration and creation of seminar papers and other forms of knowledge testing (e-Blitz, e-Test, e-Quiz).

The SMSCentar and SAN system, supported by the smsCRM application (Customer Relationship Management via SMS), present possibilities for a wide range of information services, based on interactive communication through text messages, available to both 


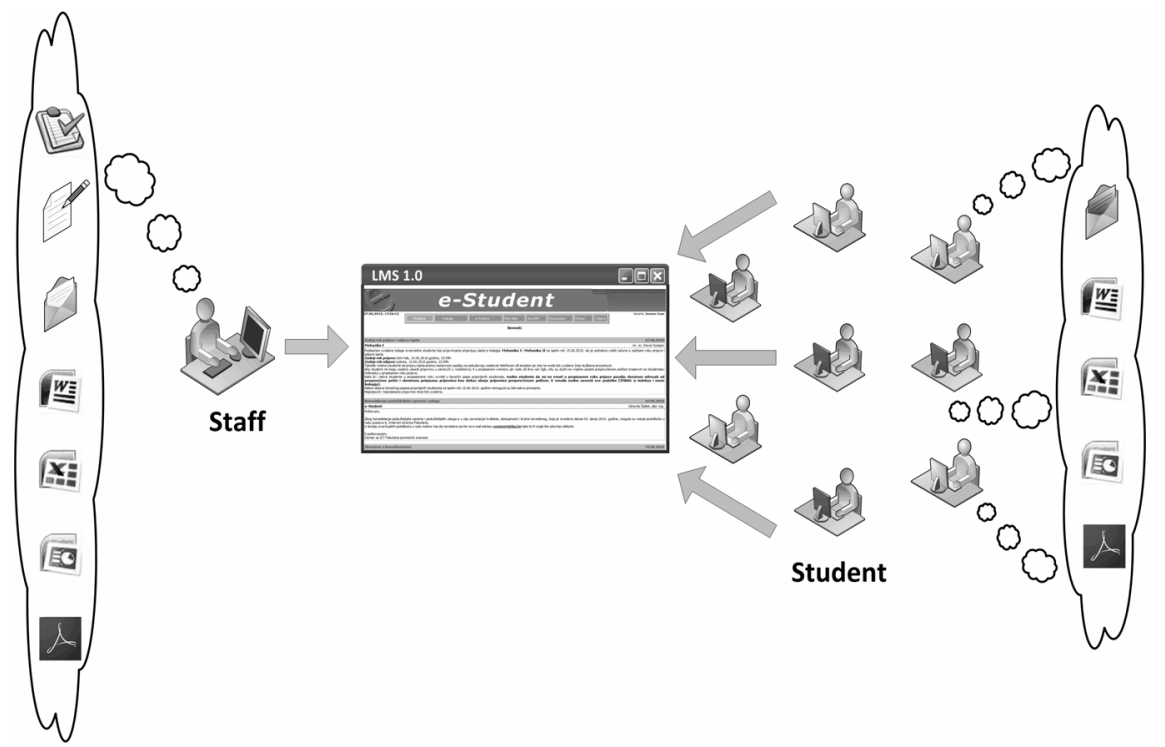

Fig. 2. LMS in use at the Faculty of Transport and Traffic Sciences

students and the Faculty staff alike. The current interactive services available to sudents, which are connected to the PCLab, are the services of obtaining the status of computers and booking of the same in the PCLab (Peraković, Remenar, \& Jovović, 2010). By sending an apropriate text message to the SMSCentre phone number, the SMSCentre will forward the request to the SAN Server module, which in turn sends a message containing the information about the status of the computer in the desired computer lab to the SMSCenter. The message also contains infomation on the location of the PC Lab, date and time of the message creation, working hours for that particular day, total number of available computers, number of the computers students are working on, number of computers available for use, as well as the number of booked computers.

There is a whole range of possible additional usages of SMS with the aim of improving the quality and speed of informing the participants of the teaching process about changes in the schedule of lectures and practical courses, the current status of a seminar paper, exam dates and consultation hours of the teachers, exam results, reporting of computer malfunctions etc. The modularity of this system enables quick implementation of new services developed in accordance with the ideas and suggestions provided by the teaching and non-teaching staff as well as students.

Within the last three years yet another module has been added to the e-Learning system of the Faculty in the form of an interactive application, called FPZmobile, which provides real time information to students through mobile terminal devices. The basic idea was to develop an application which would offer accurate and up-to-date information about the Faculty and students' achivements (seminars, practical courses, preliminary exams, etc.) to all students while studying at the Faculty in the form adapted for viewing on interfaces of mobile terminal devices such as mobile phones, PDA devices and Smartphones. As the target users of the application are students, it was thought best to develop an application which could be used with as many mobile terminal devices as possible. By using this 
application, users would have access to the relevant information at any given time, regardless of their location or terminal equipment they are using. The FPBmobile application was developed within the Java 2 Micro Edition (J2ME) environment intended for mobile terminal devices. The reasons behind this choice arise from the fact that there are numerous different operational systems on the mobile terminal device market and they all support applications developed in J2ME environment (Peraković, Jovović, \& Forenbacher, 2009).

All systems are based on communication realized through SQL database as well. This enhances the modularity of the system, i.e. upgrading and system changes are made easy, which in turn makes it possible to adapt the system for operation at other faculties.

\section{Implementation results}

The modularity of this system enables quick implementation of new services developed in accordance with the ideas and suggestions provided by the teaching and non-teaching staff as well as students. The LMS system of the Faculty of Transport and Traffic Sciences has been in function for 6 calendar years, i.e. 5 full academic years, and has been used by 362 users for 509 courses. The entire system is used by 7,489 students which represents $100 \%$ of the courses in the undergraduate, pre-graduate and graduate studies.

\subsection{Positive implementation results}

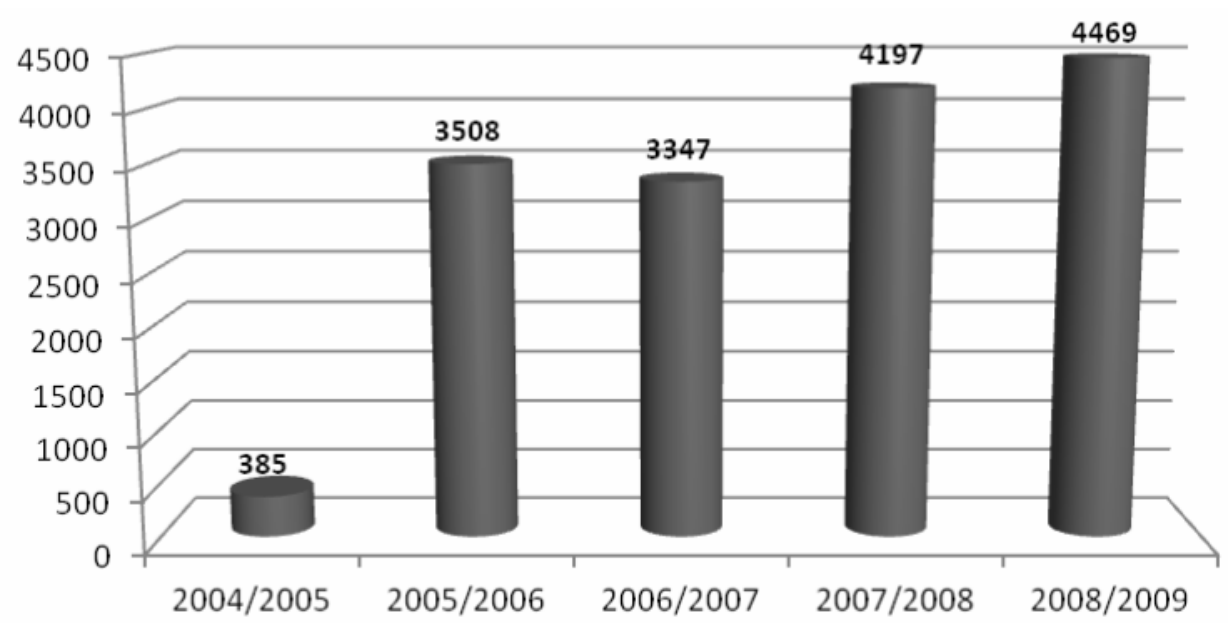

Fig. 3. Submitted topics for seminar papers

Within 5 academic years, the system has been used 836,870 times by students when submitting 15,906 topics for seminar papers (Fig. 3) for as many as 15,033 seminar papers. At the same time the teaching staff used the system 48,444 times to give out 2,742 announcements for their students and publish 5,645 data files of teaching materials as shown in Fig. 4.

The implementation of the system indicated the positive aspects of studying at the Faculty of Transport and Traffic Sciences brought about by the LMS system. Students have accepted the freedom of studying with the support that the LMS system provides extremely well. 


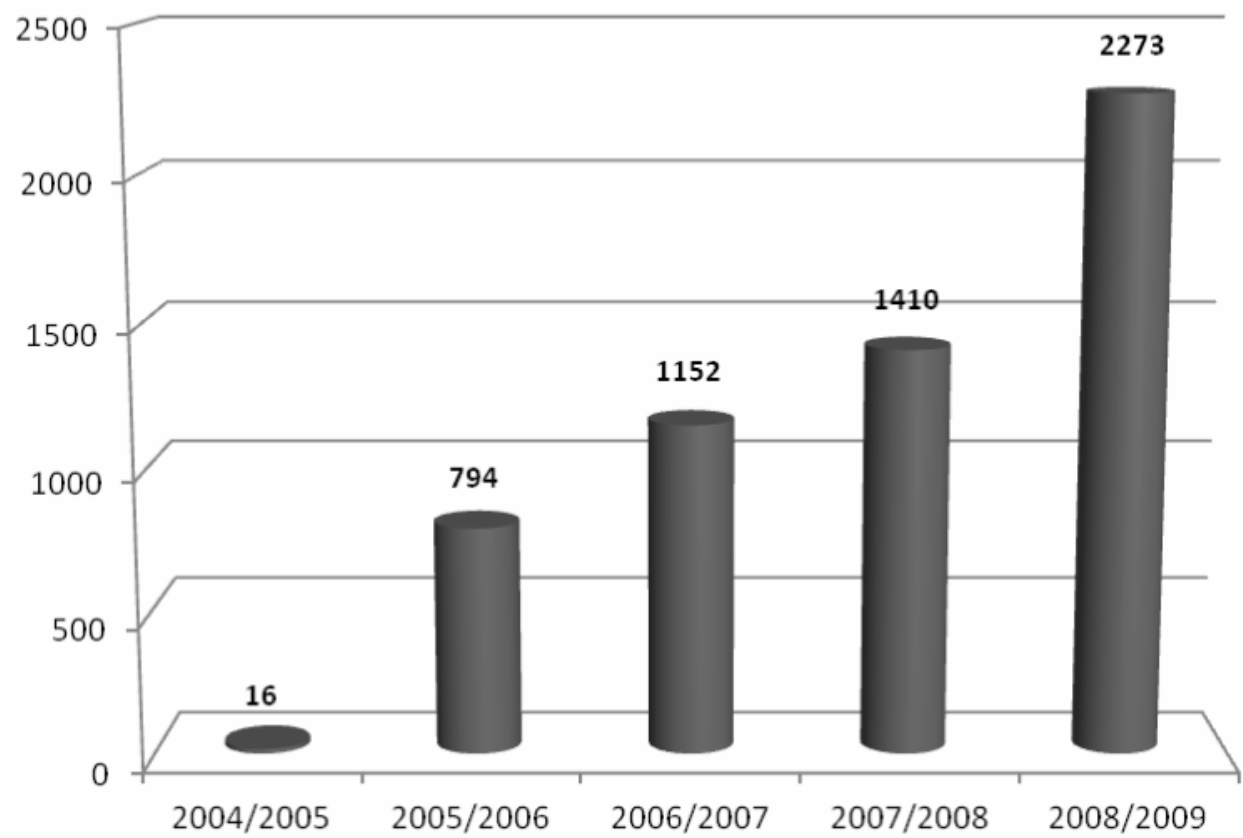

Fig. 4. Published teaching materials

Throughout academic years the number of students working on their tasks in the period between midnight and 8 am has been increasing gradually, whereas the number of students working between 8 am and 4 pm has been falling constantly.

It is also important to notice that the number of submitted seminar papers grows with each new academic year and in the academic year 2008/2009, compared with the year 2007/2008, the number of submitted seminar papers rose by $27 \%$, as shown in Fig. 5 . In order to maintain the quality level of the study program, the number of refused seminar papers and seminar papers graded with a D increased significantly in the academic year 2008/2009, whereas the number of seminar papers graded with a B or A dropped.

Fig. 6 shows continuous improvement of the teaching staff in using e-Test knowledge testing which resulted in a $200 \%$ higher number of published e-Tests in the academic year 2008/2009 compared with the academic year 2007/2008.

\subsection{Negative implementation results}

Although there are many advatages to using e-Learning, and surveys and research present e-Learning as a very positive way of learning and one that will be used in the future, drawbacks are often neglected and need to be looked into in order to find a solution.

The basic drawback to any e-Learning system lies in the IT equipment every student needs to possess. A fast Internet connection is very often necessary to manage almost real time communication between either instructors and students or students themselves, to download teaching materials or take exams. Although the e-Learning system in educational institutions is frequently set up as an addition to the traditional way of learning, regular 


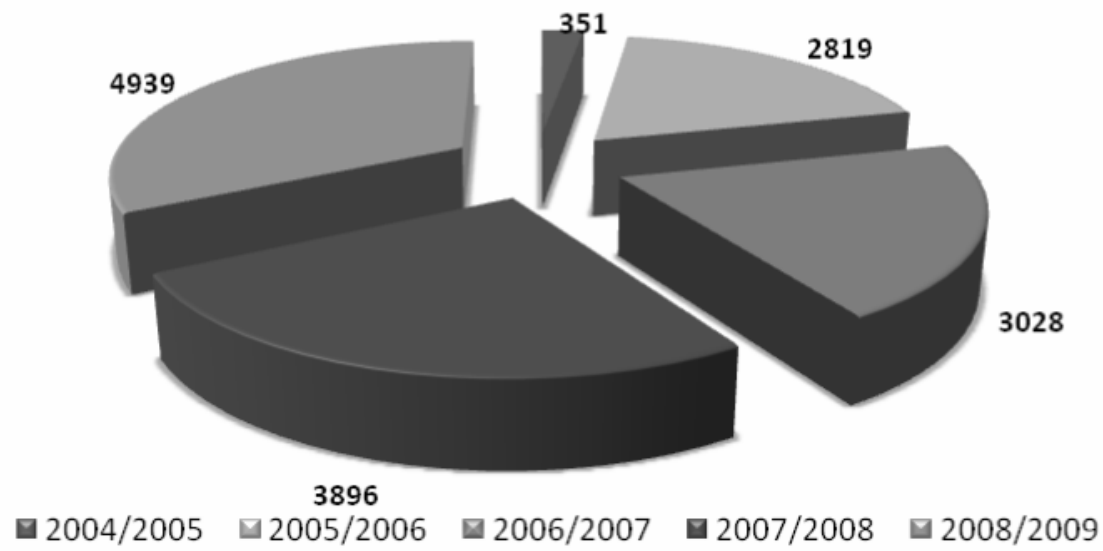

Fig. 5. Posted seminar papers

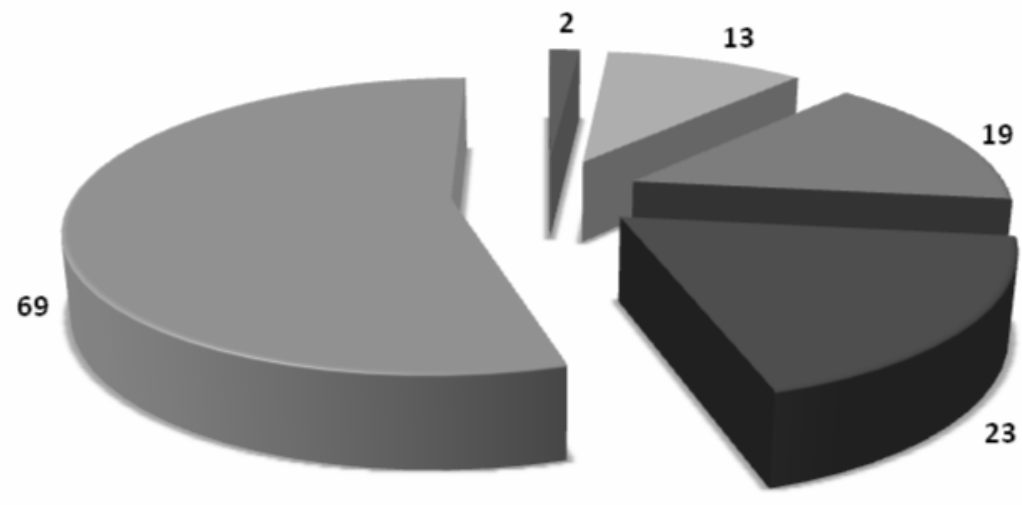

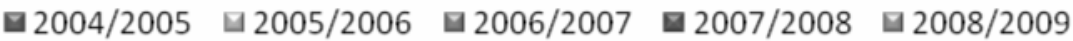

Fig. 6. Published e-Tests per year

maintenance of the equipment at the Faculty is often necessary to support this way of teaching. In order to reach the full potential of e-Learning it is necessary for students to have computers with Internet access. (Peraković, Kavran, \& Remenar, 2006)

As the number of e-Tests grew (Fig. 6), it became obvious that a certain number of students were always trying to cheat, whether they were taking exams in a traditional way or by using the e-Learning system for testing of their knowledge. The solution to this problem is complex and starts with giving students authorisation, then monitoring the way students research teaching materials, and finally defining the time for taking exams and randomly choosing questions when applying e-Testing. The availability of materials enables students to cheat when writing seminar papers by submitting someone else's and/or publicly available papers as their own. This problem can be partially eliminated by monitoring the way papers are 
created and submitted and by browsing the titles and contents of the papers. The downside to this is that students are required to use the e-Learning system right from the beginning of their studies, while working on their seminar papers, taking exams and finally writing their final thesis. Creating an electronic file containing all relevant information on a student may significantly contribute to minimizing the chances of deceiving the system.

The lack of interaction between both instructors and students and students themselves leads to the feeling of isolation. It is more difficult to do group work when using e-Learning system than when using traditional methods with a group of students in the same classroom. By developing social networks and implementing collaboration systems like forums and exchanges of real time e-mail messages, as well as video conferencing systems, it is possible to mitigate the feeling of a computer being an instructor and students being isolated and dislocated. There are indicators which show that people with lower self-esteem manage to improve their interaction when using e-Learning as they can voice their attitudes and opinions without revealing their true identity.

\section{Development of a new LMS system}

Many advantages as well as disadvantages and technological obsoleteness have been noticed in the last 6 calendar years, i.e. 5 academinc years, during which the current LMS has been in function. Furthermore, while developing and using the current LMS, new insights and knowledge have been gained, which will be used in designing a new LMS.

It will be possible to design the new system according to the model proposed in this paper. The model suggests the use of up-to-date Web 2.0 technologies and principles, compliance with the European Commission guidelines, adaptation to the Bologna education model, ISVU system and the "Outcomes of Studying at the University of Zagreb" program ("Ishodi učenja na Sveučilištu u Zagrebu" - SveZaIU, 2009). Furthermore, the proposed LMS 2.0 model needs to enable efficient and simple use of the system to people with disabilities.

\subsection{The European Commission Guidelines}

When developing a new LMS, special attention will be paid to the relevant European Commission guidelins, starting with the e-Learning initiative proposed by the European Commission, and aiming at the realization set by the European Council in Lisbon. Ways to mobilize education and train communities, as well as economic, social and cultural development have been devised, all with the prupose of accelerating the process of introducing knowledge society. (COMMISSION OF THE EUROPEAN COMMUNITIES, 2000) As there is a cause-and-effect link between the development of information and communication technologies (ICT) and LMS, a question arises about defining and separating of the mentioned concepts since learning in a technology enriched environment (e-Learning) cannot be mistaken for learning about technology (learning about 'e'). For this reason, while developing a new LMS, special attention will be paid to the conclusions of the European Commission which proposes distancing initial and expert educational policies for teachers and instructors from thechnical skills while empowering all participants in educational process to develop new competencies and master media and digital literacy as well as ingrate the above into the daily educational environment. The modular framework for ICT use in education and its integration into education spurs better understanding of the changes in educational processes and educational goals whose fulfillment and implementation have been supported by ICT. (EUROPEAN COMMISSION, 2003) 


\subsection{The old system of studying}

By signing the Bologna Declaration, the Republic of Croatia abandoned the old system of studying which had be fashioned according to the German concept of studying, so called Fachhochschule.

The current LMS in function at the Faculty of Tansport and Traffic Sciences was designed and developed for the purposes of studying according to the old system of studying. As such, it could not fully support the priciples of studying according to the Bologna Process. Due to extreme complexity of the current LMS in function, it is not possible to adapt the system to the Bologna Process. The curent LMS will have to be shut down completely and a new one will be developed in accordance with the conceptual model proposed here.

\subsection{The Bologna Declaration and process}

The Republic of Croatia signed the Bologna Declaration in 2001. Its purpose is to create a universal higher education body and enable a range of advantages for students such as:

- accepting the system of easily recognizable and comparable levels, among other by implementing the Diploma Supplement in order to promote employment of European citizens and international competitiveness of the European higher education system.

- Accepting the system based on two main cycles, undergraduate and postgraduate. In order to enter the second cycle, it is necessary to complete the first cycle lasting at least 3 years. The level achieved after the first cycle needs to correspond to the qualification requirements of the European labout market. The second cycle will enable obtaining of the Master's and/or Doctorate degree, as is the case in many European countries.

- The implementation of a credit system, such as ECTS, as a suitable means of promoting widespread student exchange. Credits may be gained outside the higer education system, including life long learning, provided they are recognized by the university which is accepting the student.

- Promoting mobility by overcoming obstacles to free movement, particularly: giving students a chance to learn, granting them access to the studies and relevant services; acknowledging and evaluating the time teachers, researchers and administrative staff have spent researching, leacturing or studying, without prejudging their statutory rights.

- Promoting European cooperation in ensuring quality with the aim of developing comparable criteria and methodologies.

- Promoting the necessary European dimension of higher education, esapecially in developing curricula, inter-institutional cooperation, mobility schemes and integrated programs of studies, training and research.

Furthermore, the Bologna model of studying introduces two important concepts: life-long learning with continuous monitoring of a student during the course of studies.

The model of the proposed LMS will include a possibility of providing continuous access to the system to the students who have already graduated. Former students will therefore be able to access all the materials they may need in their work. Furthermore, by being granted continuous access, the students who have already graduated are able to contact their teachers, former colleagues as well as graduate students. The goal of life long education can thus be achieved, and new possibilities of cooperation between former students and their teachers, current students and the institution itself present themselves.

Continuous monitoring of student acheivements throughout their studies is implemented in order to achieve higher quality of education. An electronic dossier (e-Dossier) has been developed, which both students and instructors have access to. The E-Dossier is a collection 
of relevant data on a student from the time of enrollment to graduation. It contains, among other information, basic information about a student and information on the taken e-Tests, topics of seminar papers, data about seminar papers such as the title, description and grade, information about the student's use of computer labs, information about practical work and similar. As students progress through their studies, their e-Dosiers are automatically updated with all the activities connected to the studies.

E-Dossiers provide instructors with an insight into the students' progress and possible adaptations to the students' needs. By using e-Dossier, it can be become apparent that a certain student, throughout his studies, shows great interest in working with information systems as he/she uses them when writing seminar papers and exercises. Based on this information, the student may be offered to write his/her final paper or thesis on the topic he/she shows interest in, i.e. in the field of information systems.

The most significant advantage for students is the possibility of having their e-Dossiers, which show their interests and their work throughout their studies, printed out. A printed copy of the e-Dossier may be attached to letters of application when looking for a job as a proof of their interest in a certain field or the like.

\subsection{Adaptation to specific requirements of studying in the Republic of Croatia}

Although the suggested model is universally applicable, specific requirements of studying in the Republic of Croatia make it necessary to design parts of the system according to those requirements. Possible problems which would warant deviations from the universal system include student mentality, simultaneous execution of the studies according to the old program and to the Bologna process, usage of the Information System of Higher Education Institutions (Informacijski sustav visokih učilišta - ISVU) which is applied at universities in the Republic of Croatia, as well as the "Results of Studying at the University of Zagreb" program.

Unfortunately, student mentality in the Republic of Croatia still implies, for some students, attempts of cheating at exams and plagiarizing of seminar papers. A fuzzy logic model for browsing the LMS was developed, among other things, for this purpose (Peraković, Remenar, \& Grgurević, 2008). It allows instructors to browse easily through papers and discover plagiarized seminar papers. In order to prevent students from copying and sharing answers while taking e-Tests, a logic of assigning exam questions and showing multiple answers was devised. There is also a possibility of restricting the choice of location where students can take e-Tests. It is possible, for example, to limit e-Test taking only to the computer labs at the Faculty within a strictly defined time frame.

The universities in the Republic of Croatia are still in a transitional period between the old system of studying and the Bologna process. As older students are still active in taking exams and will be in the foreseeable future, the conceptual model proposed here implies providing support for those students. Although the majority of functionalities is the same for both "old" and "new" students, there are certain differences and it is necessary to automatically adapt the LMS to the way of studying of each individual student. The LMS, therefore, enables the students studying according to the Bologna process to access all functionalities demanded by the Bologna Declaration, whereas for the old students these functionalities are invisible and they are not able to use them.

At universities in the Republic of Croatia the ISVU system is used for monitoring student achievements and other organizational tasks. As in the future the LMS model suggested here should be able to fully exchange information with the ISVU system, special attention was paid to the manner of formatting data for information exchange. The ISVU system has 
options for importing and exporting data and the LMS was designed in such a way to halfautomatically or automatically generate and manipulate XML and CSV data files. Even though the ISVU system is still relatively closed and it is not possible to access data directly, the authors of this chapter hope that it will be possible in the near future.

\subsection{Adaptation for students with disabilities}

Although there are very few students with disabilities at the Faculty of Transport and Traffic Sciences, all students need to be able to use the LMS without difficulty. In order to enable students with certain disabilities to use the system, it will be developed in full compliance with all HTML and CSS standards, as well as in accordance with 508 Accessibility Guidelines. Furthermore, in order to facilitate ease of use for visually impaired students, the LMS design will incorporate the option of high contrast colors and text magnification. It will also include applications which enable blind persons to use the Internet (web readers).

\subsection{LMS and Web 2.0 - LMS 2.0}

Over the last several years, the Web 2.0 concept has significantly altered the paradigm of user participation on the Internet, shifting from the passive, "read only" kind of participation to full, active participation of all users in content creation. The definitions of the Web 2.0 paradigm vary considerably from author to author; however, they are not mutually exclusive, since each definition includes the concept of active user participation in content creation, collaboration, as well as knowledge and information sharing (Grosseck, 2009). As such, the Web 2.0 constitutes the ideal platform for LMSs within which students become active participants in content creation, thus changing learning paradigms. As can be seen from the overview provided in this paper, students already play a significant role in creating content within the LMS. With the application of Web 2.0 paradigms, services and technologies in instructional processes and LMSs most drawbacks can be overcome (Peraković, Remenar, \& Kavran, 2008), which will contribute to the quality of instructional processes as well as enable students to participate more fully in content creation. Virtually any Web 2.0 technology or service may be applied in the LMS 2.0 model. Most authors agree that blogs, microblogs, wikis, RSS feeds, tag-based folksonomies, social bookmarking, multimedia content sharing, forums and social networking sites are becoming a crucial part of the tertiary level educational process, as presented in Table 1, (Grosseck, 2009).

Although Web 2.0 technologies and services provide a number of advantages, such as allowing students freedom and flexibility, some of those listed may have negative effects on student education. For instance, the Wikipedia exerts practically no control over the information which is entered. The information is often incorrect or has not been verified, which is very difficult for instructors to monitor and respond to in timely fashion. For this reason, the new generation model, LMS 2.0, proposes the incorporation of Web 2.0 technologies (wiki, forum, tag-based folksonomies, social bookmarking, RSS, social networking) within the LMS in order to maintain the quality, accuracy and up-to-date character of important instructional materials and information. In contrast, some Web 2.0 services are used as an external addition to the LMS, (Facebook, Twitter, Academia.edu, LinkedIn, etc.), as can be seen in Fig. 7.

According to this conceptual model, the basic principles on which the e-Student system operates, described earlier on in this paper, remain practically the same. Students will continue to access instructional materials added by instructors, register topics for seminar 


\begin{tabular}{|c|c|}
\hline $\begin{array}{c}\text { Web } 2.0 \\
\text { technology }\end{array}$ & Educational application \\
\hline Blogging & $\begin{array}{ll}\text { - } & \text { use blogs for real-world writing experiences } \\
\text { - } & \text { pull class blogs together into one area for easy tracking } \\
\text { - } & \text { quickly give feedback to students, and students to each other } \\
\text { - } & \text { update new information such as homework and assignments } \\
\text { - } & \text { using comments in blogs can encourage students to help each } \\
\text { other with their writing, and get responses to a question } \\
\text { without getting the same answer twenty times etc. }\end{array}$ \\
\hline Microblogging & $\begin{array}{l}\text { - classroom community, exploring collaborative writing, reader } \\
\text { response, collaboration across schools, countries, project } \\
\text { management, assessing opinion, platform for metacognition, } \\
\text { conference or as part of a presentation or workshop, for } \\
\text { reference or research, facilitating virtual classroom discussion, } \\
\text { creating a learning experience, a Personal Learning Network } \\
\text { use for dissemination of teachers' publications and materials, } \\
\text { locating original sources of ideas, quotes, allows for very } \\
\text { focused and concrete feedback to students to refine their } \\
\text { thinking and improve their skills, fostering professional } \\
\text { connections, informal research, for storytelling, follow a } \\
\text { professional, get feedback on ideas, event updates, live } \\
\text { coverage of events, build trust, build a community etc. }\end{array}$ \\
\hline Wiki & 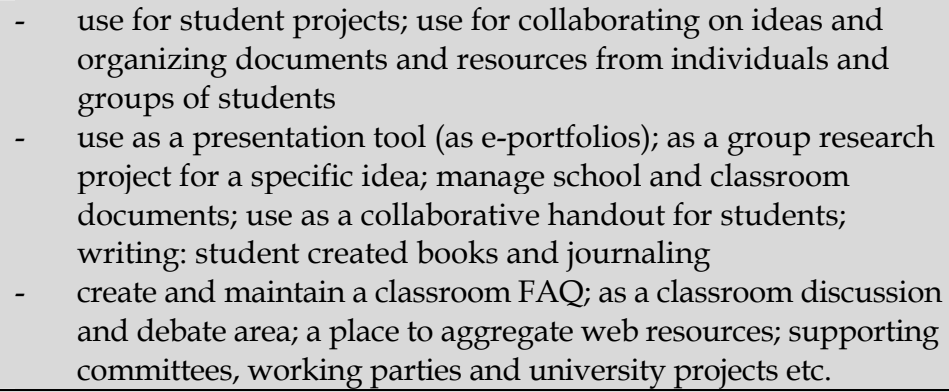 \\
\hline $\begin{array}{l}\text { Photo/Slides } \\
\text { sharing }\end{array}$ & $\begin{array}{l}\text { - } \\
\text { share, comment, and add notes to photos or images to be used } \\
\text { - } \quad \text { inspire writing and creativity; create a presentation using the } \\
\text { photos } \\
\text { - } \\
\text { use tags to find photos of areas and events around the world } \\
\text { for use in the classroom. } \\
\text { post student presentations to an authentic audience and get } \\
\text { feedback from around the world; share professional } \\
\text { development materials and have it available anywhere, } \\
\text { anytime, to anyone; post presentations of special events }\end{array}$ \\
\hline Video sharing & $\begin{array}{l}\text { video professional development on own terms; create an own } \\
\text { subject specific videos with students; use video sharing sites to } \\
\text { find videos on current issues etc. }\end{array}$ \\
\hline
\end{tabular}




\begin{tabular}{|c|c|}
\hline $\begin{array}{l}\text { Syndication of } \\
\text { content through } \\
\text { RSS }\end{array}$ & 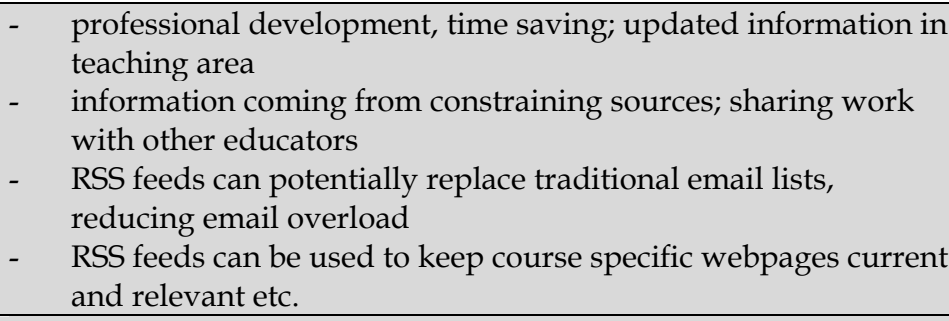 \\
\hline $\begin{array}{l}\text { Social } \\
\text { bookmarking }\end{array}$ & $\begin{array}{l}\text { - create a set of resources that can be accessed on any computer } \\
\text { connected to the internet; conduct research and share that } \\
\text { research with peers } \\
\text { track author and book updates; groups of students doing a } \\
\text { classroom project sharing their bookmarks; rate and review } \\
\text { bookmarks to help with students decide on usefulness of } \\
\text { resources; setup a group tag in order to share educational } \\
\text { resources } \\
\text { share one del.icio.us account between a number of different } \\
\text { subject specific educators in order to share resources with each } \\
\text { other etc. }\end{array}$ \\
\hline $\begin{array}{l}\text { Social } \\
\text { Networking }\end{array}$ & $\begin{array}{l}\text { - event support and continuation, team and community support, } \\
\text { aggregation of social media applications, personal learning } \\
\text { environments etc. }\end{array}$ \\
\hline Other tools & $\begin{array}{l}\text { - instant messaging increase the sense of community and } \\
\text { accessibility which is required for collaborative learning; VoIP } \\
\text { can promote international collaborations and understanding; } \\
\text { calendars make calendar events, homework, anything you } \\
\text { want available on mobile devices connected to the Internet } \\
\text { survey and polls, online diagrams and web-based word } \\
\text { processor, on-line spreadsheet, social search, mind mapping; } \\
\text { virtual worlds - virtual conferences and seminars, team } \\
\text { meetings and collaboration spaces, simulations etc. }\end{array}$ \\
\hline
\end{tabular}

Table 1. Models of integrating Web 2.0 technologies in higher education (Grosseck, 2009)

papers as well as submit them, take e-tests and the like. Adding Web 2.0 functionalities will introduce a range of new services and benefits.

Wiki: According to the creators of the original wiki concept, a wiki is a collection of interlinked web pages which can be freely expanded, i.e. a database which any user may edit with ease. Users may visit, read and easily add or alter the content. Wikis have attracted the attention of educational processes because of the advantages they offer, their simplicity and ease of use. Studies show an increase in use for educational purposes. Wikis are considered to be effective learning and teaching tools since they facilitate collaborative learning and collaborative writing, support project-based learning as well as promote creativity and critical thinking (Usluel \& Mazman, 2009). In this proposed model, the wiki system has been implemented in the LMS in order to control the content, which would allow the quality to remain constant. Each student has the opportunity to create, edit and add to the wiki content; however, instructors can easily correct errors and deal with possible omissions, all in one place. It is possible to create wiki content with every entry, whether it is 


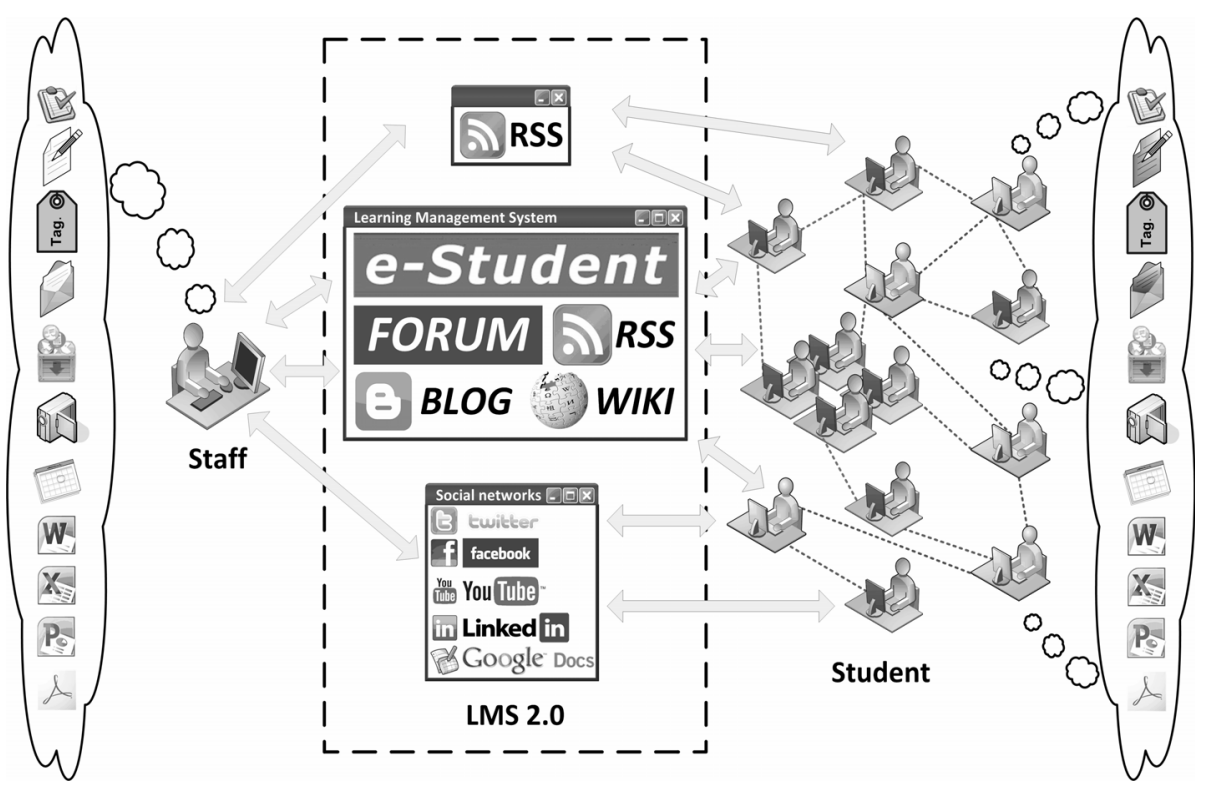

Fig. 7. Conceptual Model of LMS 2.0 at the Faculty of Transport and Traffic Sciences

related to an institute, department, instructor, or a course, teaching unit, lecture, seminar paper or e-test, which would complement the available instructional materials.

Blog: Blogs are also called online diaries. These allow users who possess no technical skills to create, publish and organize their web pages, which contain personal views and opinions presented in chronological order. Studies indicate that blogs develop writing skills, encourage critical thinking and collaborative learning, as well as provide feedback. Blogs may effectively serve as personal online diaries which allow students to share files, resources and knowledge. Furthermore, blogs may function as personal e-portfolios which allow students to track their personal successes, thoughts, achievements and development, (Usluel \& Mazman, 2009). For these reasons, the blog constitutes one of the essential Web 2.0 technologies in this conceptual model. Each student will be able to maintain their own blog as well as create blog entries for particular elements within the LMS. For instance, every student will be able to create a blog entry containing his/her review of a particular teaching unit or lecture, which will contribute to the development of their critical thinking and investigative spirit.

RSS: RSS (most commonly expanded as Really Simple Syndication) is a family of web feed formats used to publish frequently updated works - such as blog entries, news headlines, audio, and video-in a standardized format. An RSS document (which is called a "feed", "web feed", or "channel") includes full or summarized text, plus metadata such as publishing dates and authorship. Web feeds benefit publishers by letting them syndicate content automatically. They benefit readers who want to subscribe to timely updates from favored websites or to aggregate feeds from many sites into one place. RSS feeds can be read using software called an "RSS reader", "feed reader", or "aggregator", which can be web-based, desktop-based, or mobile-device-based. (RSS, 2010). The new LMS generation, according to 
the concept proposed in this paper, will offer the option of distributing multiple RSS feeds, whether these are RSS feeds of particular courses, institutes, departments, instructors or any other entity within the LMS, such as instructional materials and seminar papers. In this way, students can keep up with new information on an almost real-time basis. Furthermore, this model enables each student or instructor to use the LMS as an RSS aggregator, i.e. to aggregate and read their favorite RSS feeds within the LMS, as well as share them with user groups within their social networks or with individual users.

Forum: Online or threaded discussions have been in use for a decade, and therefore a larger body of research literature exists that examines how to use them, what they accomplish, and how to evaluate them. The research on online discussions soon claimed a number of advantages to their use in online and hybrid courses. They increased collaboration, a sense of community, depth and higher-order thinking, interaction, think time, reflection and time on task (Meyer, 2010). In addition to a typical forum which allows students and instructors to post unconnected topics, the new LMS generation will offer the option of starting a discussion topic for each entity within the LMS. For instance, it will be possible to start a discussion on any lecture or file, which will stimulate students' critical thinking, active participation and investigative spirit. On the other hand, instructors will be able to see what their teaching or a particular teaching unit may be lacking, which will enable continuous development and an increase in the quality of instruction and instructional materials.

Social networks: Social networks are applications which facilitate collaboration, sharing of knowledge, interaction and communication between users who are based in different locations but have common interests, needs or goals. Social networks may be viewed as pedagogical tools which encourage the discovery and sharing of information, bring together and maintain networks of people as well as aid the preservation of relationships between members, (Usluel \& Mazman, 2009). The application of social network principles within the LMS serves to increase communication between students. The proposed concept specifies the necessity of creating several types of social networks within the LMS. Two networks are predefined: one is a network of students in the same department and the other a network of students taking the same course. The third network would be created personally by each student according to his/her wishes and preferences. In addition to the internal social network, there will also be indirect communication (via RSS feeds) towards independent social networks such as Facebook, LinkedIn, Twitter and so on.

Implementing the above will enable fully flexible creation and editing of content, as well as tagging, storing and sharing of content between students, instructors and previously described social networks (Fig. 8.). Since all these modules make up the LMS of the institution, the entire content may be verified and its quality kept constant.

\subsection{Integration with other Faculty systems}

Further development of the system will lead towards integrating the e-Student, DMS, SAN, SMSCentar and FPZmobile systems with the other systems at the Faculty: Studomat and ISVU. Integration of all Faculty systems into a single system would simplify the work of both instructors and students. Integration would result in a single set of access data, i.e. a single username and password which would be used to access any system. It would also result in the exchange of student data across systems and a single electronic file for each student. Adapting the visual identity to the needs of system users will make the system significantly easier to use. (Peraković, Remenar, \& Jovović, 2010) 


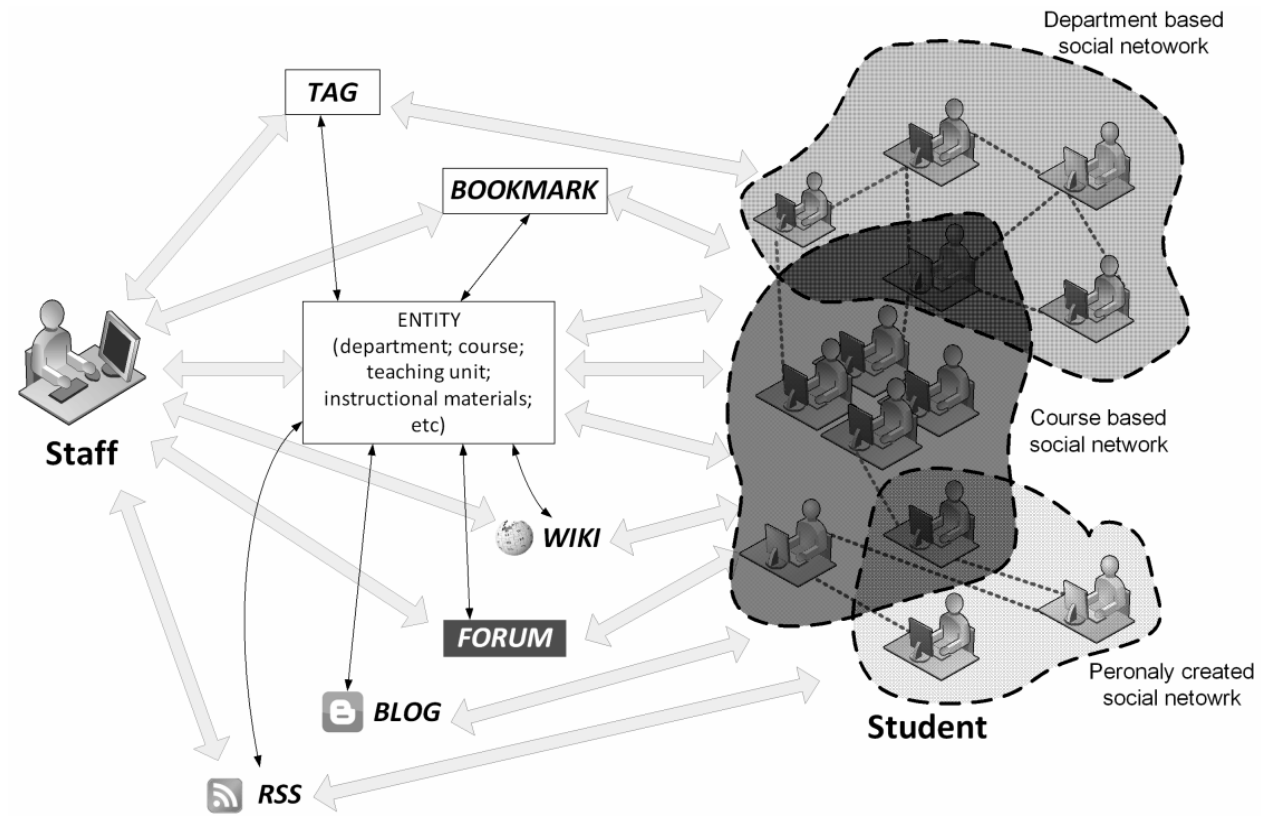

Fig. 8. Creating, editing, tagging, storing and sharing of content

\subsection{Security}

The fact that the LMS is based on web application modules developed within the institution emphasizes security issues apparent in easy accessibility and a large number of users. It is a priority - not simply an incidental benefit - to maintain a reliable level of functionality and a high level of data security while using and maintaining the LMS, as well as developing new modules. Security testing for existing types of attack is continuously carried out in order to remove hidden flaws, oversights and shortcomings in timely fashion. This serves to protect the distance learning application modules, users and user data stored in the databases used by the LSM. It is crucial to extend the protection beyond the LMS itself, so that organizational, programmatic and structural security mechanisms are implemented and applied to the entire information and communication system of the Faculty. Other services which are in use must also be included, such as the ISVU or the accounting system, as well as specific applications used by the faculty staff. In order to achieve a secure and reliable integral information system of the Faculty of Transport and Traffic Sciences, it is crucial to provide both teaching and non-teaching staff with continuous training on security issues and the risks of transacting business electronically, as well as using a digital signature in the instructional process. It hardly requires explicit mention that the adopted security policy of applying the information and communication infrastructure of the Faculty of Transport and Traffic Sciences must be adhered to fully and unconditionally (Peraković \& Remenar, 2007).

\section{Conclusion}

An analysis of the e-Learning system developed within the institution and in use for the past six years, leads to the conclusion that the present system has become indispensable in 
electronic communication, both regarding the instructional process and student welfare. Thus, the Faculty of Transport and Traffic Sciences has become one of the leading faculties in Croatia in using the assistance of new technologies to aid students in the acquiring and evaluation of knowledge.

An overview of the statistical data concerning the use of the e-Learning system of the Faculty of Transport and Traffic Sciences indicates that there is great interest in system, and, what is more significant, the interest continues to grow. Both students and users have demonstrated a ready acceptance of the functionalities which have been developed so far, and they want and expect further expansion as well as the development of new system options. The greatest value of the system lies in the fact that it has been developed in its entirety at the Faculty of Transport and Traffic Sciences, in coordination with its teaching staff and students. Thus, the students may advance their knowledge and skills using new information and communication technologies and program tools on projects developing information systems, in a teamwork environment.

By means of conducting continuous surveys of user satisfaction with the current e-Learning system, as well as taking into consideration new requirements and rectifying possible errors, the new e-learning system of the Faculty will continue to develop.

Since a completely new system is about to be developed, it will be designed taking into consideration the goals mentioned above, but it will also aim to support and be integrated with Web 2.0 services. The new system will upgrade the processes of information exchange and publication, which will be adapted to the needs of each student by means of e-mail and text messages, as well as RSS feeds and integration with popular social networks such as Facebook and Twitter. Finally, people with disabilities will be able to use this LMS 2.0 model simply and efficiently. The LMS 2.0 will be designed fully in accordance with the model proposed in this paper, which is centered around the proposed use of up-to-date Web 2.0 technologies, compliance with European Commision Guidelines, adaptation to the Bologna education model, the ISVU system and the "Outcomes of Studying at the University of Zagreb" program.

\section{References}

COMMISSION OF THE EUROPEAN COMMUNITIES. (24 May 2000). COMMUNICATION FROM THE COMMISSION. e-Learning - Designing tomorrow's education .

EUROPEAN COMMISSION. (November 2003). Education and Training 2010. Information and Communication Technologies in Education and Training .

Grosseck, G. (2009). To use or not to use web 2.0 in higher education? Procedia - Social and Behavioral Sciences , 1 (1), 478-482.

Hage, H., \& Aimeur, E. (2010). E-learning for the new generations, a Web 2.0 approach. In M. Buzzi, \& M. Buzzi (Ed.), E-learning (pgs. 1-18). Vukovar, Croatia: In-teh.

Hargadon, S. (04. March 2009). Web 2.0 Is the Future of Education. Retrieved on 15 January 2010 from Steve Hargadon's blog: http:/ / www.stevehargadon.com/2008/03/web20-is-future-of-education.html

Hijon-Neira, R., \& Velazquez-Iturbide, A. (2010). From the discovery of students access patterns in e-learning including web 2.0 resources to the prediction and enhacements of students outcome. In R. Hijon-Neira, \& R. Hijon-Neira (Ed.), Elearning, experiences and future (pgs. 275-294). Vukovar, Croatia: In-Teh.

Huddlestone, J., \& Pike, J. (2008). Seven key decision factors for selecting e-learning. Cognition, Technology \& Work, 10 (3), 237-247. 
Mason, R., \& Rennie, F. (2007). Using Web 2.0 for learning in the community. Internet and Higher Education, 10, 196-203.

Meyer, K. A. (2010). A comparison of Web 2.0 tools in doctoral course. Internet and Higher Education, $\mathrm{xxx}-\mathrm{x} x \mathrm{x}$.

Molina, A. I., Giraldo, W. J., Jurado, F., Redondo, M. A., \& Ortega, M. (2010). Evolution of Colaborative Learning Enviroment based on Desktop Computer to Mobile Computing: A Model-Based Approach. In S. Soomro, \& S. Soomro (Ed.), E-learning, experiences and future (pgs. 261-274). Vukovar, Croatia: In-Teh.

Peraković, D., \& Remenar, V. (2007). Security Audit and Mechanism of Protecting eLearning System an the Faculty of Transport and Traffic Sciences. Proceedings of the 10th International Conference on Information and Intelligent Systems (pgs. 311-317). Varaždin: Faculty of Organization and Informatics.

Peraković, D., \& Remenar, V. (2007). Security Audit and Mechanism of Protecting eLearning System at the Faculty of Transport and Traffic Sciences. Proceedings of the 10th International Conference on Information and Intelligent Systems (pgs. 311-317). Varaždin: Faculty of Organization and Informatics.

Peraković, D., Jovović, I., \& Forenbacher, I. (2009). Analysis of the Possibilities and Effects of Implementing Interactive Application for Mobile Terminal Devices in m-Learning System at the Faculty of Transport and Traffic Sciences. Posters Abstracts of the ITI 2009 31st International Conference on Information Technology Interfaces (pgs. 27-28). Cavtat / Dubrovnik: SRCE, University Computing Centre.

Peraković, D., Kavran, Z., \& Remenar, V. (2006). The Impact of Introducing e-Learning System in the Teaching Process at the Faculty of Traffic and Transport Sciences. In B. Katalinić (Ed.), Proceeding of 17th International DAAAM Symposium (pgs. 299-300). Vienna: DAAAM International.

Peraković, D., Remenar, V., \& Grgurević, I. (2008). Possibility of Applying Fuzzy Logic in the e-Learning System. Proceedings of the 19th Central European Conference on Information and Intelligent Systems (pgs. 89-94). Varaždin: Faculty of Organization and Informatics.

Peraković, D., Remenar, V., \& Jovović, I. (2010). Conceptual Model of Developing a New LMS System of the Faculty of Transport and Traffic Sciences. Poster Abstracts of The ITI 2010 32th International Conference on Information Technology Interfaces. Cavtat / Dubrovnik: SRCE, University Computing Centre.

Peraković, D., Remenar, V., \& Kavran, Z. (2008). Drawbacks of Implementing e-Learning System in the Teaching Process at the Faculty of Transport and Traffic Sciences. Poster Abstracts of The ITI 2008 30th International Conference on Information Technology Interfaces (pgs. 225-26). Cavtat / Dubrovnik: SRCE University Computing Centre.

Peraković, D., Remenar, V., \& Šašek, Z. (2007). Analysis of Operation and Possibilities of Improving e-Learning System in Traffic Engineering. Promet - Traffic ETransportation , 19 (3), 167-172.

RSS. (7 June 2010). Retrieved on 24 June 2010 from the Wikipedia: http://en.wikipedia.org/wiki/RSS

Saeed, N., \& Sinnappan, S. (2010). Effects of Media Richness on User Acceptance of Web 2.0 Technologies in Higher Education. In R. Hijón-Neira, \& R. Hijón-Neira (Ed.), Advanced Learning (str. 233-244). Vukovar, Croatia: In-Teh.

SveZaIU. (2009). Ishodi učenja na Sveučilištu u Zagrebu. Zagreb: Sveučilište u Zagrebu.

Usluel, Y. K., \& Mazman, S. G. (2009). Adoption of Web 2.0 tools in distance education. Procedia - Social and Behavioral Sciences , 1 (1), 818-823.

Wal, T. V. (2 February 2007). vanderwal.net. Retrieved on 25 January 2010 from Folksonomy: http://vanderwal.net/folksonomy.html 


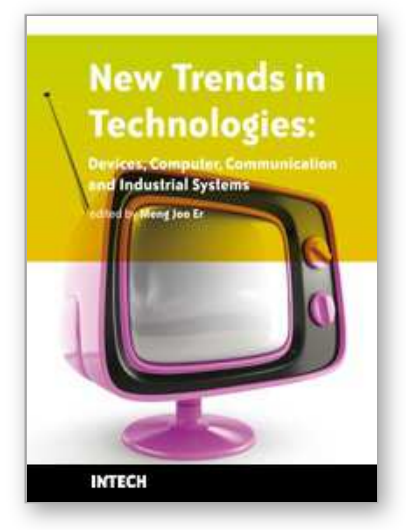

\section{New Trends in Technologies: Devices, Computer, Communication and Industrial Systems}

Edited by Meng Joo Er

ISBN 978-953-307-212-8

Hard cover, 444 pages

Publisher Sciyo

Published online 02, November, 2010

Published in print edition November, 2010

The grandest accomplishments of engineering took place in the twentieth century. The widespread development and distribution of electricity and clean water, automobiles and airplanes, radio and television, spacecraft and lasers, antibiotics and medical imaging, computers and the Internet are just some of the highlights from a century in which engineering revolutionized and improved virtually every aspect of human life. In this book, the authors provide a glimpse of new trends in technologies pertaining to devices, computers, communications and industrial systems.

\section{How to reference}

In order to correctly reference this scholarly work, feel free to copy and paste the following:

Vladimir Remenar, Ivan Jovovic and Dragan Perakovic (2010). Model of the New LMS Generation with UserCreated Content, New Trends in Technologies: Devices, Computer, Communication and Industrial Systems, Meng Joo Er (Ed.), ISBN: 978-953-307-212-8, InTech, Available from: http://www.intechopen.com/books/newtrends-in-technologies--devices--computer--communication-and-industrial-systems/model-of-the-new-Imsgeneration-with-user-created-content

\section{INTECH}

open science | open minds

\section{InTech Europe}

University Campus STeP Ri Slavka Krautzeka 83/A 51000 Rijeka, Croatia Phone: +385 (51) 770447 Fax: +385 (51) 686166 www.intechopen.com

\section{InTech China}

Unit 405, Office Block, Hotel Equatorial Shanghai No.65, Yan An Road (West), Shanghai, 200040, China 中国上海市延安西路65号上海国际贵都大饭店办公楼405单元 Phone: +86-21-62489820

Fax: +86-21-62489821 
(C) 2010 The Author(s). Licensee IntechOpen. This chapter is distributed under the terms of the Creative Commons Attribution-NonCommercialShareAlike-3.0 License, which permits use, distribution and reproduction for non-commercial purposes, provided the original is properly cited and derivative works building on this content are distributed under the same license. 